\title{
THE EFFECT OF ELECTRIC CIGARETTE NICOTINE LEVELS ON PEAK EXPIRATORY FLOW IN VAPE USER COMMUNITIES, SOUTH JAKARTA
}

\author{
Hesketh Hans' ${ }^{1}$, Mila Citrawati²), Citra Ayu Aprilia3) \\ ${ }^{1)}$ Study Program of Medical, Faculty of Medicine, UPN "Veteran" Jakarta \\ 2) Department of Physiology, Faculty of Medicine UPN "Veteran" Jakarta \\ 3) Department of Pharmacy and Pharmacology, Faculty of Medicine \\ UPN "Veteran" Jakarta
}

\begin{abstract}
Background: Electronic Cigarette is one form of many nicotine replacement therapy (NRT) that uses energy from battery to deliver nicotine in gas form and by World Health Organization (WHO) defined as Electronic Nicotine Delivery System (ENDS). This study aimed to investigated the effect of electronic cigarette's nicotine dosage on the peak expiratory flow (PEF).

Subjects and Method: This was a cross sectional study conducted at VH CommunitySouth Jakarta from February to march 2018. A Sample of 72 vapers was selected by consecutive sampling. It was divided into 3 groups: vapers who used $3 \mathrm{mg}, 6 \mathrm{mg}$, and 12 mg nicotine dosage. The inclusion criteria were electric smokers healthy participants aged 19-24 years, normal body mass index, moderate physical activity, and only used ecigarettes for more than 12 months. The exclusion criteria were the respondent had a history of respiratory disease. The dependent variable was peak expiratory flow (PEF). The independent variable was the nicotine dosage which obtained in electronic cigarette's liquid. The research instrument used by Peak Flow Meter (PFM). The data was analyzed by Chi-square.

Results: Chi-Square analysis showed the effect of electronic cigarette's nicotine dosages to $\mathrm{PEF}(\mathrm{OR}=7.2 ; \mathrm{p}<0.001)$.

Conclusion: The result showed that nicotine dosage which obtained in electronic cigarette's liquid had effects with PEF. Therefore, each nicotine dosage has different effects to respiratory health. Because nicotine increases endothelial permeability, inhibits cell endothelial proliferation, and caused goblet cell metaplasia.
\end{abstract}

Keyword: Electronic Cigarette, Nicotine, Peak Expiratory Flow

\section{Correspondence:}

Mila Citrawati. Departemen Fisiologi, FK UPN "Veteran" Jakarta. Jl. RS Fatmawati, Pondok Labu, South Jakarta 12450. E-mail: milacitrawati@upnvj.ac.id. Mobile: (021) 7656971 